\title{
Paleodemographics of Child Sacrifice at Midnight Terror Cave: Reformulating the Emphasis of Maya Sacrificial Practices
}

\author{
Michael G. Prout, James E. Brady \\ Department of Anthropology, California State University, Los Angeles, Los Angeles, USA \\ Email: jbrady@cal statela.edu
}

How to cite this paper: Prout, M. G., \& Brady, J. E. (2018). Paleodemographics of Child Sacrifice at Midnight Terror Cave: Reformulating the Emphasis of Maya Sacrificial Practices. Archaeological Discovery, 6, 1-20.

https://doi.org/10.4236/ad.2018.61001

Received: October 16, 2017

Accepted: December 12, 2017

Published: December 18, 2017

Copyright $\odot 2018$ by authors and Scientific Research Publishing Inc. This work is licensed under the Creative Commons Attribution International License (CC BY 4.0).

http://creativecommons.org/licenses/by/4.0/

\begin{abstract}
Investigations of Midnight Terror Cave, Belize between 2008-2010 recovered a human osteological assemblage of over 10,000 bones, the largest reported for a cave in the southern Maya lowlands. Analysis indicates that approximately a quarter of the bones belong to subadults, which make up $43 \%$ of the minimum number of individuals (MNI). Determination of age at death produced a mortality curve that differs significantly from a normal curve with the numbers peaking between 5 - 10 years of age, when mortality is generally low. These figures are similar to those produced from the Cenote of Sacrifice at Chichen Itza. The large percentage of subadults suggests that children were much more important in Maya human sacrificial practices than generally recognized.
\end{abstract}

\section{Keywords}

Maya, Child Sacrifice, Demographics, Mortality Curve, Midnight Terror Cave

\section{Introduction}

The study of human sacrifice has had a strange history in Maya archaeology. At the turn of the $20^{\text {th }}$ century, Edward Thompson dredged the Cenote of Sacrifice, recovering a large assemblage of artifacts and human bone. Thompson's dredging appeared to corroborate Bishop Diego de Landa's $16^{\text {th }}$ century account of offerings-including human victims-being thrown into the well. Although Thompson's research at the Cenote of Sacrifice was widely known to archaeologists, it was a popular account (Willard, 1926) that propagated images of the sacrifice of "beautiful virgins" at the well. 
Current models of Maya sacrifice view most victims as men. Demarest and co-authors' (1997) argument that warfare contributed to the Maya collapse has archaeologists using the Central Mexican ethnohistorical record to formulate models of Maya sacrifice. Accounts of huge numbers of war captives being sacrificed at the dedication of the sixth renovation of the Templo Mayor in 1487 have been particularly influential in creating the expectation that a sacrificial assemblage will consist overwhelming of young adult males. The evidence of the large-scale sacrifice of male warriors in the Ciudadela at Teotihuacan provides archaeological evidence that buttresses this model (Spence et al., 2004). Similarly, William Fowler (1984) found that most of the sacrificial victims at Chalchuapa were male.

The problem with the discussion of sacrifice in general is that it focuses almost exclusively on adults. This paper presents data on subadult remains recovered from Midnight Terror Cave (MTC), Belize. The analysis of this material will show that age at death departs radically from a normal mortality curve and instead resembles the age composition encountered in the remains from the Cenote of Sacrifice at Chichen Itza. Additionally, we will show that child sacrifice was much more central to Maya practices than previously appreciated.

\section{Caves and Human Remains}

The presence of human skeletal remains in Maya caves is not unusual. James E. Brady (1989) identifies dozens of caves where human remains have been reported, however, so few details are generally provided that it is difficult to interpret the deposits. Until the 1990s almost all human remains found in caves were treated as burials despite Oliver Ricketson's (1925) observation that caves are not usual burial places. This reflected the fact that until near the end of the last century, most archaeologists still believed that caves were used principally for habitation. Cave burial was a logical extension of the idea of cave habitation. As Andrea Cucina and Vera Tiesler (2014) note, "The continuity between the realm of death and that of the living is expressed in the common use of residential spaces as depositional areas for the deceased [Fitzsimmons \& Shimada, 2011; López Austin, 1980; Malvido et al., 1997; Manzanilla \& Serrano, 2003] (p. 227).” Although J. Eric Thompson (1975) dismissed the possibility of any long-term habitation simply because caves are so damp and humid, this did not lead to a general reexamination of the nature of human skeletal material in caves.

Jane Buikstra (2007) notes that academic consideration of sacrifice only developed after 1960. Cave archaeology, however, did not begin to address the issue until more intensive and critical studies in the 1990s demonstrated that caves functioned as important ritual sites in Maya sacred geography. As a result, human skeletal remains found in caves have tended to be interpreted in terms of their role in ritual. The first attribution of death due to sacrifice was a child found in Eduardo Quiroz Cave with two unhealed punctures in its skull (Pendergast, 1971) but this appears to have made little impact on the thinking of the 
time. A number of years later, Dorie Reents-Budet and Barbara MacLeod (1986) attributed the presence of a number of children's skeletons found cemented into rimstone dams to sacrifice. The recovery of another child's skeleton, with perimortem puncture wounds in its skull, was argued to represent sacrifice at NajTunich (Brady, 1989). Importantly, Brady's discussion was the first to detail means of separating burial from sacrifice at a site containing evidence of both burials and sacrifice. Unlike the more general discussions of sacrifice focused on adults, the early cave archaeological examples were grounded in physical evidence of trauma associated with child sacrifice.

\section{Investigation of Midnight Terror Cave}

Midnight Terror Cave is located in the Cayo District of Belize, approximately 10 $\mathrm{km}$ south of Belmopan near the modern Mennonite village of Springfield [Figure 1]. During the Late Classic (600 - 900 A.D.) the cave was situated within $1 \mathrm{~km}$ of the ancient Maya center of Tipan Chen Uitz. The cave was reported to the Belizean Institute of Archaeology (IoA) in 2006 after a looter was seriously injured in a fall. The IoA conducted a brief inspection and reported a high concentration of human remains, most dating to the Classic Period [250 CE - 925 CE]. A three-year surface survey was conducted from 2008-2010 by California State University, Los Angeles (CSULA) working with the Belize Valley Archaeological Reconnaissance directed by Dr. Jaime Awe. The project collected over 10,000 bones and bone fragments from the surface of the cave floor. No excavations were conducted in part because examination of the numerous looters pits failed to disclose the presence of subsurface deposits.

MTC is divided into eight major areas, called Operations, based on natural boundaries within the cave [Figure 2]. Only two of the Operations, V and VIII, yielded large quantities of bone [Table 1]. Interestingly, few human bones were found in the cave's entrance chamber, Operations III and IV. Operation III contains a number of altars that would have been passed as one descended from the entrance to the floor of the cave. Operation IV has the heaviest concentration of ceramics in the cave as well as a large constructed plaza on which public rituals were held. Thus, while these two areas have heavy concentrations of artifacts, the types of rituals conducted there did not generally include human sacrifice. Those rituals were conducted deeper in the cave.

Operation V is located in the lowest chamber of the cave. A number of constructed terraces near the entrance of the chamber would have provided standing room for spectators to observe rituals performed on a platform constructed around a speleothem column [Figure 3]. Near the end of the chamber, an altar is flanked by additional terraces. The altar is at the top of a gentle slope that is covered with human bones cemented in place by calcite, which were left in place and not included in the MTC inventory. Shielded by a screen of speleothems, the deepest recess in Operation $\mathrm{V}$ contains a muddy depression that forms a seasonal pool containing large quantities of bone [Figure 4]. The stacked arrangement 


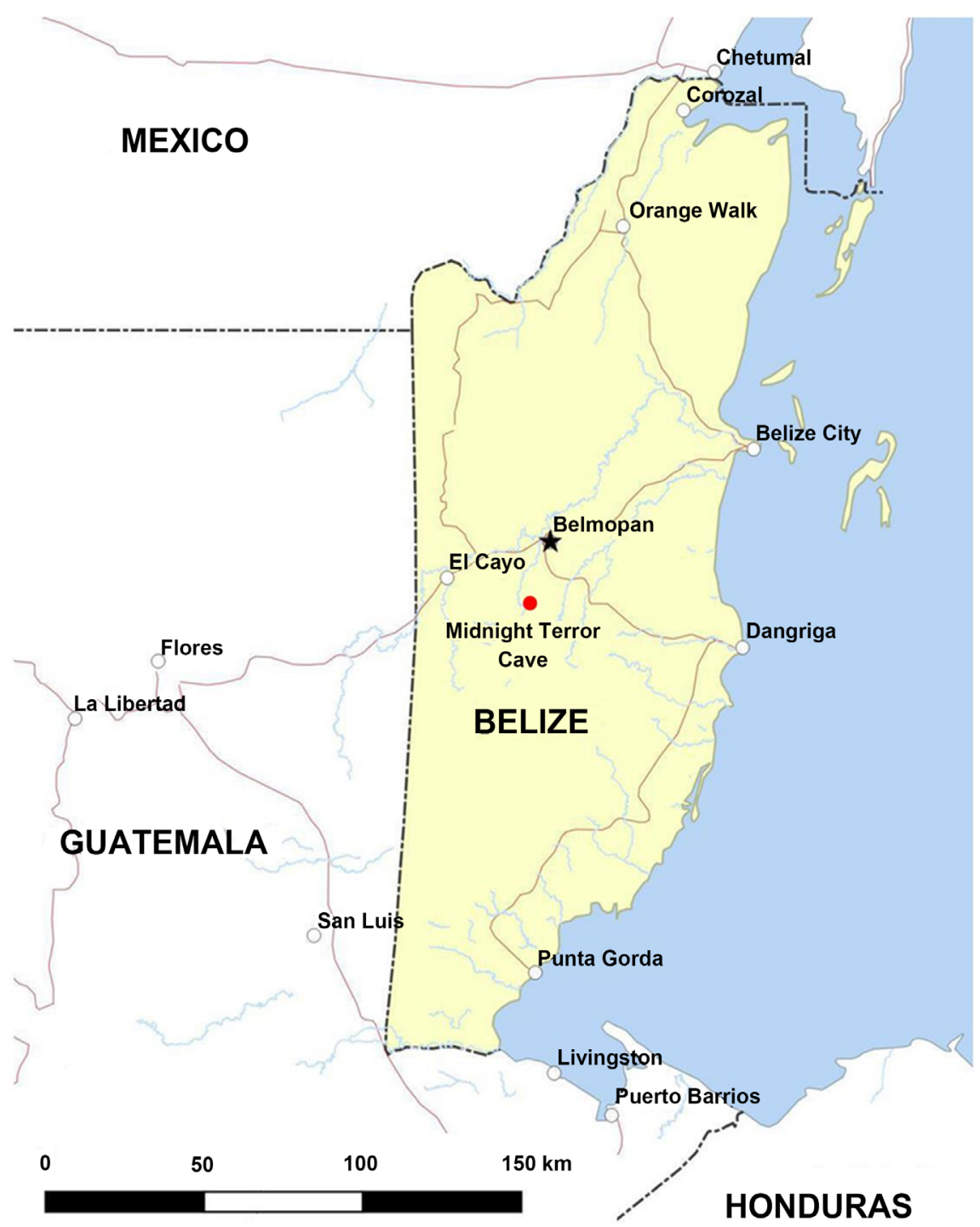

Figure 1. Map of Belize with the location of Midnight Terror Cave.

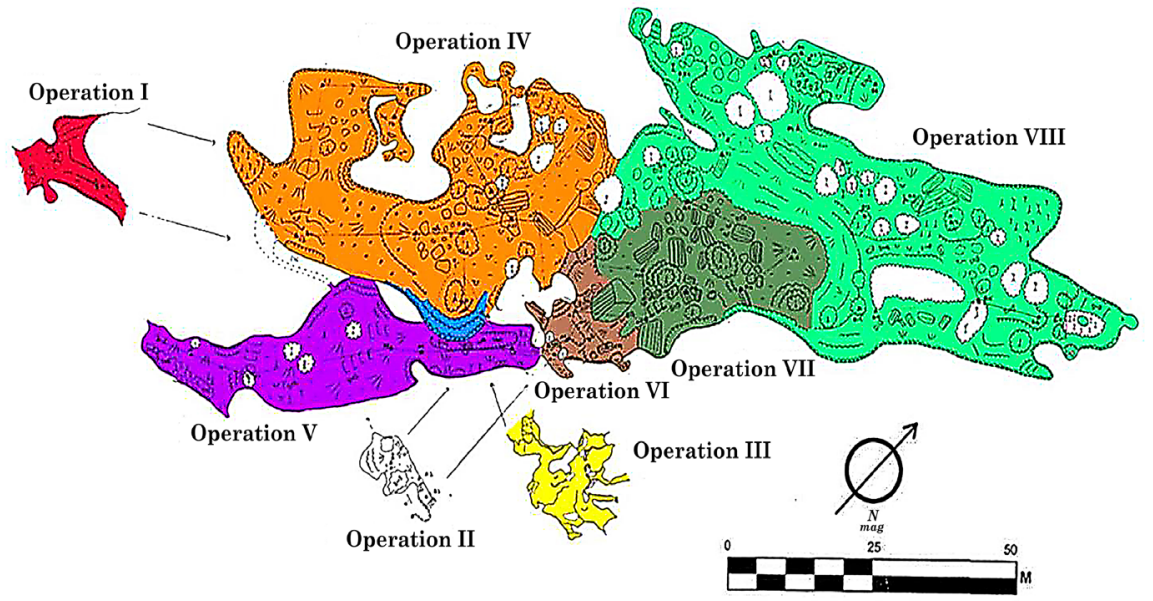

Figure 2. Map of Midnight Terror Cave depicting the major divisions (operations) of the cave. 


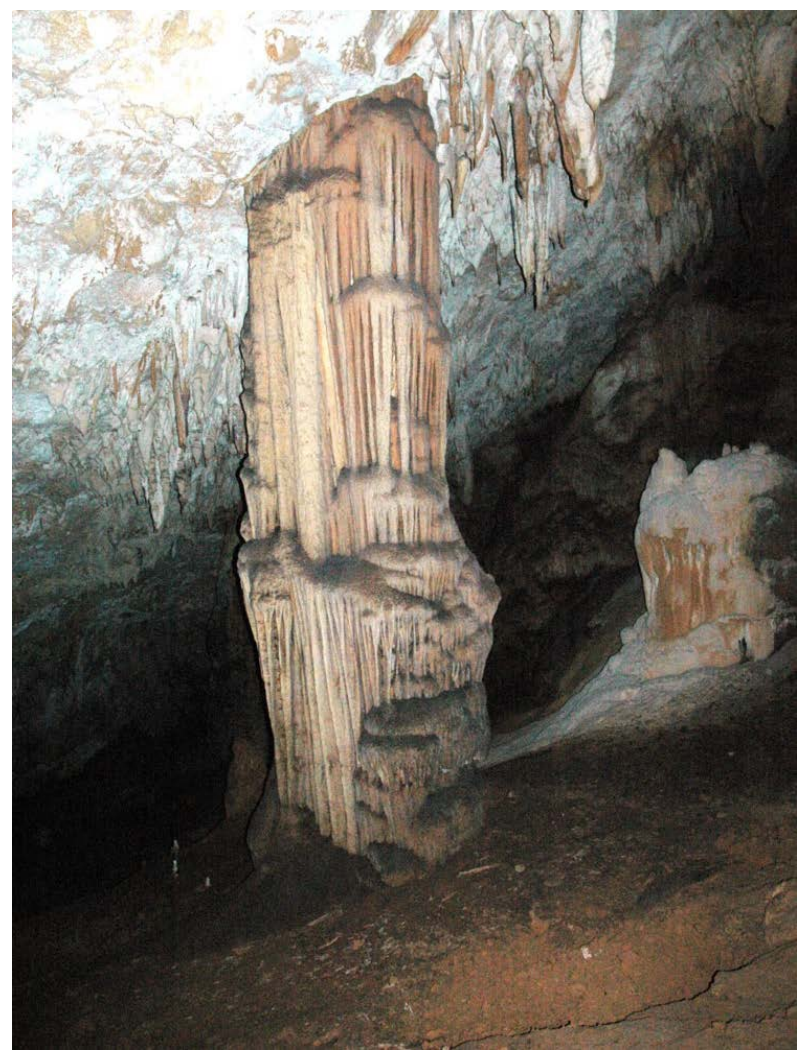

Figure 3. A leveled platform was constructed around this large speleothem in Operation V.

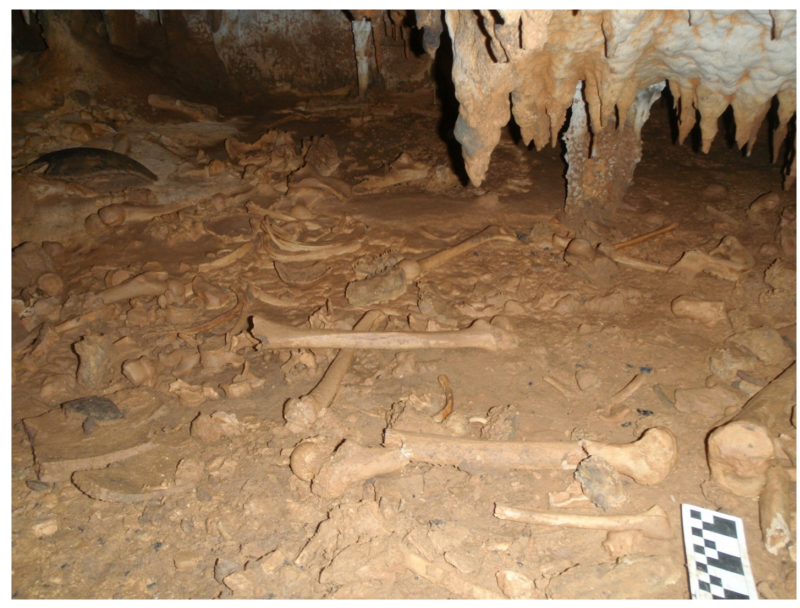

Figure 4. Bone scatter on the floor of the seasonal pool in Operation V.

of some of the long bones suggests secondary placement [Figure 5]. Space is extremely limited in this chamber so it is thought that, rather than being the site of sacrifices, it may represent a place where bone was deposited following the ritual cleaning of the public spaces in preparation for a new ceremony (Scott, 2009).

Operation VIII is the highest chamber in the cave, located on a shelf overlooking a large constructed plaza in Operation VII. The broad, level floor in 
Table 1. Distribution of skeletal material by operation within Midnight Terror Cave.

\begin{tabular}{ccccc}
\hline OPERATION & ADULT QTY. & PCT. & SUBADULT QTY. & PCT. \\
\hline Operation I & 0 & 0.0 & 0 & 0.0 \\
Operation II & 0 & 0.0 & 0 & 0.0 \\
Operation III & 6 & 0.1 & 3 & 0.1 \\
Operation IV & 12 & 0.2 & 0 & 0.0 \\
Operation V & 1054 & 16.6 & 265 & 12.1 \\
Operation VI & 480 & 7.6 & 40 & 1.8 \\
Operation VII & 304 & 4.8 & 8 & 0.3 \\
Operation VIII & 4277 & 67.5 & 1866 & 85.9 \\
Special Deposits & 201 & 3.2 & 9 & 0.4 \\
\hline
\end{tabular}

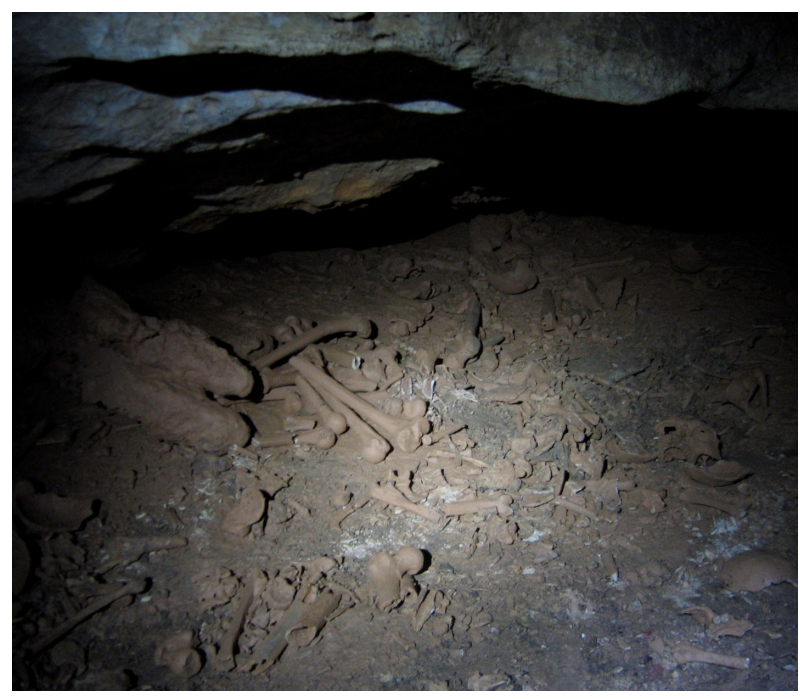

Figure 5. Long bones stacked amidst many smaller fragments. A majority of the surrounding osteological scatter is long bone fragments.

Operation VII, resembling the plaza in Operation IV, was clearly constructed for public ritual. Operation VIII on the other hand is broken by formations and so lends itself to private rituals. The floor of Operation VIII is mostly travertine and contains many shallow pools fed by water dripping from formations throughout the year.

\section{Sacrifice at Midnight Terror Cave}

During the first season of fieldwork, the skeletal material was interpreted as belonging to sacrificial victims based on a number of characteristics that have been noted as being associated with sacrifice. Carrie Anne Berryman (2007) makes the point that sacrifice shows a "lack of investment in grave preparation (p. 394)." Absent in MTC is any reverential posthumous treatment that would have pre- 
vented the scattering, commingling, and trampling which will be discussed in the next section.

The deposition of bodies on the surface of MTC illustrates a second characteristic of sacrifice, which is the "placement of bodies in highly visible public or ceremonial spaces (in contrast to the typical residential mortuary patterns for the region...)" (Berryman, 2007: p. 394). Clearly, bodies are being displayed when left in plain view on the cave floor along pathways. Another of Berryman's traits associated with sacrifice is the lack of grave offerings. Nothing resembling mortuary offerings was found at MTC. In fact, the two areas with heavy concentrations of bone, Operations V and VIII, are precisely those with low densities of any other type of artifact. Finally, although "signs of violence" are infrequent in the assemblage, 28 cases of perimortem cut marks and trauma have been recorded (Kieffer, 2017). It must be kept in mind that much of the bone is covered in calcium carbonate, which undoubtedly masks many more examples. In sum, MTC matches four of Berryman's five characteristics of sacrifice.

Attempts have been made to dismiss comingling as a characteristic associated with sacrifice by drawing an analogy to tombs where the Maya have pushed aside the bones of previous occupants to reuse the burial space. This, however, is a poor analogy. In tombs, older bones are pushed aside to make room for the new occupant who is laid out and becomes the central figure. This practice is understandable in tombs due to the limited space. Space is simply not an issue in most of the caves investigated by the authors where there is generally space for the placement of hundreds if not thousands of bodies without disturbing earlier placements. Furthermore, unlike tombs, all the bones in caves tend to be commingled.

At a higher level, analogical inferences are based on the proposition that similarities shared by two cases may reflect similarities in other areas as well. The greater the number of correspondences, the stronger the analogy (Wylie, 1985). The analogy between tombs with multiple interments and commingled cave deposits is based on both appearing to have intermingled bones. There are striking differences, however, that the analogy ignores based on the two representing very different types of behaviors. First, tombs reflect an "investment in grave preparation" which is not the case in the cave context. Second, tombs remove bodies from general view while they are exposed on the surface of caves. Thus, the analogy attempts to blur the distinction between burial and sacrifice that Berryman (2007) and others have made based simply on the fact that both superficially appear to contain mixed bones.

Caves are very specialized environments that have few if any counterparts on the surface. Cave archaeology has come to recognize a number of cave-specific contexts that can be linked with sacrifice. Darkness seems to be at the heart of what made caves special for the Maya. David Stuart notes that the ch'een (cave) glyph has a half darkened field illustrating darkness in the representation of caves (Vogt \& Stuart, 2005). In the investigation of caves, several man-made 
examples show particular attention to creating a dark zone. Brady (2012) reports a small architectural cave in which the short passage was made in the form of a $\mathrm{Z}$ to create a dark zone. Allan Cobb noted that the tunnels described by Linda Manzanilla and colleagues (1996) at Teotihuacan undulate to create a dark zone (Brady, 2004). The areas with large quantities of bone, Operations V and VIII, are the only two areas in MTC that are truly in the dark zone, and there is good reason to believe this was why these areas were selected for sacrifice.

In contrast, light zones appear to be significant in terms of mortuary practices of a very different type. Keith Prufer (1997) proposed a decade ago that rockshelters and the light zones of small caves are used for burial (also see Saul et al., 2005). This pattern is widely distributed (Coe, 1959; Lee \& Clark, 1988; Lee et al., 1988). Perhaps the only true cemetery in the Maya area is a rockshelter excavated by Juan Luis Bonor (Bonor, 1995; Bonor \& Martinez Klemm, 1995) and later by Gabriel Wrobel (Wrobel et al., 2007). Such clear evidence of burial is not what is generally found in the dark zones of caves.

Another characteristic of cave use can also be applied to the context of skeletal material. At NajTunich, which has both wet and dry areas, Brady (1989) noted that it was the wet areas that had been preferentially utilized for ritual. This relates to Maya beliefs that rain is produced in caves (Morris, 1986; Vogt, 1969) and, as a consequence, rain ceremonies are conducted in caves (Ishihara-Brito \& Guerra, 2012; Sepúlveda, 1977). There is a direct link with sacrifice in that Landa says most human sacrifice was conducted as petitions for rain (Tozzer, 1941; also note 948). One would therefore expect to find the bones of sacrificial victims in wet areas. Alternatively, one would not expect to find burials placed in areas with dripping water since the water would damage the human remains. Additionally, as already noted, wet areas are places of ritual traffic where bones could be trampled. This provides the clearest contextual evidence for distinguishing between sacrifice and burial. As noted above, both Operations V and VIII are clearly in wet areas and this is reflected in the fact that many of the bones are covered in calcium carbonate.

\section{Condition of the Assemblage}

The cave shows taphonomic changes different than those normally encountered in non-cave contexts. Vera Tiesler (2005) describes destructive factors within cave environments as follows:

Long-term extrinsic factors cause skeletal deterioration at different levels, depending on the agents involved. Some factors degrade the bony surface by covering or destroying it through erosion, encrustation, or abrasion. Other factors result in the fracture or disintegration of the whole bone unit. A third group of agents changes the original position or orientation of the skeletal segments, engendering the loss of primary relationships and increasing the disturbance of the skeletal assemblage as a whole (p. 345).

A majority of the MTC human skeletal collection exhibits degradation and 
disturbance similar to that described by Tiesler (2005). Dripping water through the calcium ceiling has left the bones partially, or fully, encased in calcium carbonate, some to the point of being cemented to the floor. Ritual circuits in the cave may also have exposed many bones to trampling beneath the feet of celebrants as the Maya made their way into the deeper recesses of the dark zones. Finally, modern looting caused incredible amounts of damage. Looters appear to have deliberately stepped on long bones. As a result, recovery of undamaged long bones was rare. Balancing the taphonomic degradation, the cave environment also helped preserve the bone. None of the material has been reduced to mush, as is too often the case at surface sites. The bones tend to retain structural integrity and are identifiable based on osteological landmarks.

\section{Methodology}

The analysis of the subadult bones was undertaken by Michael Prout at the invitation of Brady in order to explore in greater detail this area of Maya human sacrifice. Sorting began with the identification of the skeletal elements (Scheuer \& Black, 2000; Steele \& Bramblett, 1988; White et al., 2011). Side-by-side comparisons with human bones housed in the Forensic Anthropology Laboratory at CSULA were utilized as needed. Each skeletal element was examined at least four times to ensure that all subadult material was identified.

A variety of methodological approaches to age-at-death determination were employed including the comparison of size and development to known groupings (Buikstra \& Ubelaker, 1994; Goodacre, 2012; Scheuer \& MacLaughlin-Black, 1994; Scheuer \& Black, 2000; White et al., 2011), and metric analysis (Anderson et al., 1964; Black \& Scheuer, 1996; Buikstra \& Ubelaker, 1994; Danforth et al., 2009; Fazekas \& Kósa, 1978; Jeanty, 1983; Kimura, 1992; Maresh, 1970; Odita et al., 1991; Saunders et al., 1993; Tocheri \& Molto, 2002; Trotter \& Peterson, 1969; Ubelaker, 1978). Complete bones were analyzed first because estimation is most accurate when all osteological landmarks contributing to age estimates can be included in the assessment. Bones lacking diagnostic characteristics necessary to confidently assess age at death, a total of 502 bones or $22.9 \%$ of the subadult assemblage, were not assigned to age categories.

Using a modified form of Schrenk's (2017) system, age-at-death is divided into seven categories: 0 to 1 year; 1 to 2 years; 3 to 4 years; 5 to 6 years; 7 to 10 years; 11 to 14 years; and 15 to 16 years. Subadult status ends at age sixteen as skeletons in general reach full maturity by the age of seventeen (Lewis, 2007; Scheuer \& Black, 2000, 2009). Differences in growth and epiphyseal union rates become less predictable after nine years of age as nutrition, genetics, and sexual dimorphism play active roles in skeletal development (Buikstra \& Ubelaker, 1994). Linda Klepinger (2006) states, "(T)he inherent variability in the criteria of assessing biological age progressively increases from fetal life to old age (p. 42)." This is reflected in the fact that younger age ranges span one or two years while older age categories have four-year ranges. Buikstra and Ubelaker (1994) note 
that some bones reach adult morphology at a relatively young age. This leads to the under-representation of subadult bones, particularly after the age of nine, as developmentally mature elements are classified as part of the adult sample.

We chose to calculate minimum number of individuals (MNI) instead of probable number of individuals (PNI), as PNI is problematic at best when only a few matched pairs of bones are known to exist in the entire collection. Klepinger (2006) argues, “(I)n massive accumulations... MNI estimates are all that are practical, even though such numbers may grossly underestimate the true representation in the death assemblage (p. 24)." Our procedure for determining MNI follows Ubelaker and Rife (2008) and Osterholtz, et al. (2014, pp. 35-50).

\section{Results}

A total of 8525 bones were cataloged, by far the largest sample of human skeletal material recovered from a single Maya cave. After careful assessment, 2191 of the bones belong to individuals under the age of seventeen at time of death. Thus, $25.7 \%$ of the total cave assemblage is composed of subadults. Raw percentages tend to under-represent children because their bones are small making them less likely to be recovered. Our figure of children making up a quarter of all individuals being sacrificed marks a lower level boundary rather than our actual estimate of the number of children involved.

On the other hand, children's bones are more easily distinguished from each other based on size and development, resulting in MNI estimates that over-represent the ratio of children relative to adults. C. L. Kieffer (2017) provides a MNI for the entire MTC collection of 118 individuals, 46 of whom, about $39 \%$, are subadults. The current analysis recognized a MNI of 55 subadult individuals or $43 \%$ of the people represented in the cave. This appears to be considerably more than recognized by Kieffer but data on only two lots are available for comparison. In Operation VI Lot 2, only a single subadult was initially identified (Kieffer, 2017) while we recorded three [Figure 6]. In Operation VIII Lot 13, Kieffer identified two subadults. Our analysis documented at least four subadults [Figure 7]. Thus, it would appear that the MNI for the site should be revised upward and that the subadult component is larger than previously indicated.

Over the last two millennia human mortality curves across populations, both large and small, have maintained a common shape known as the bathtub curve. This engineering reliability term describes rates of early failures, random failures, and wear-out failures that appropriately fit the three segments of the human life journey: early childhood, adulthood, and senescent mortality (Bebbington et al., 2007; Lai, 2012). Kenneth Weiss and H. Martin Wobst (1973) and Vanessa Owen (2005) have presented mortality curves for various ancient and modern populations displaying the bathtub shape. The highest rate of mortality occurs within the first year of life when immune systems are not fully developed and environmental factors take their toll. After the age of one year, the death 


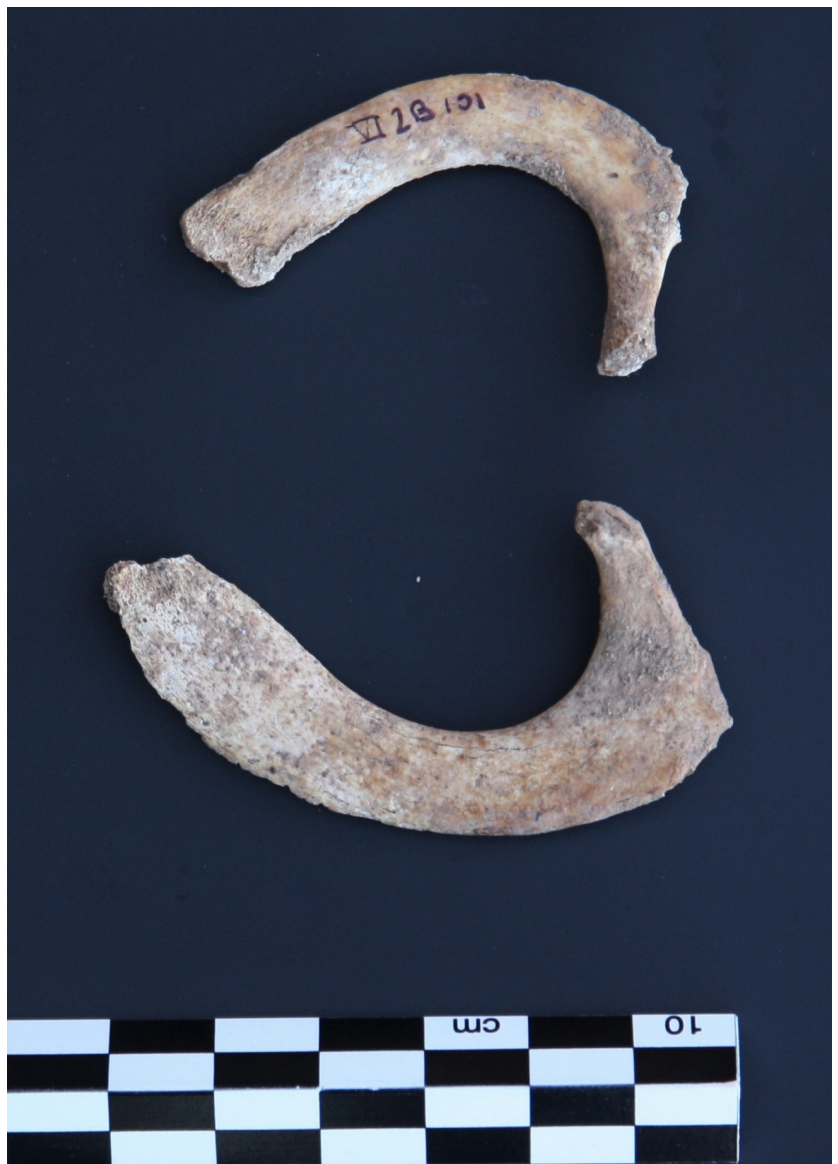

Figure 6. Two of the three subadult individuals in Operation VI Lot 02 top to bottom: Left rib 1 (VI-02b-101) and right rib 1 (VI-02b-45).

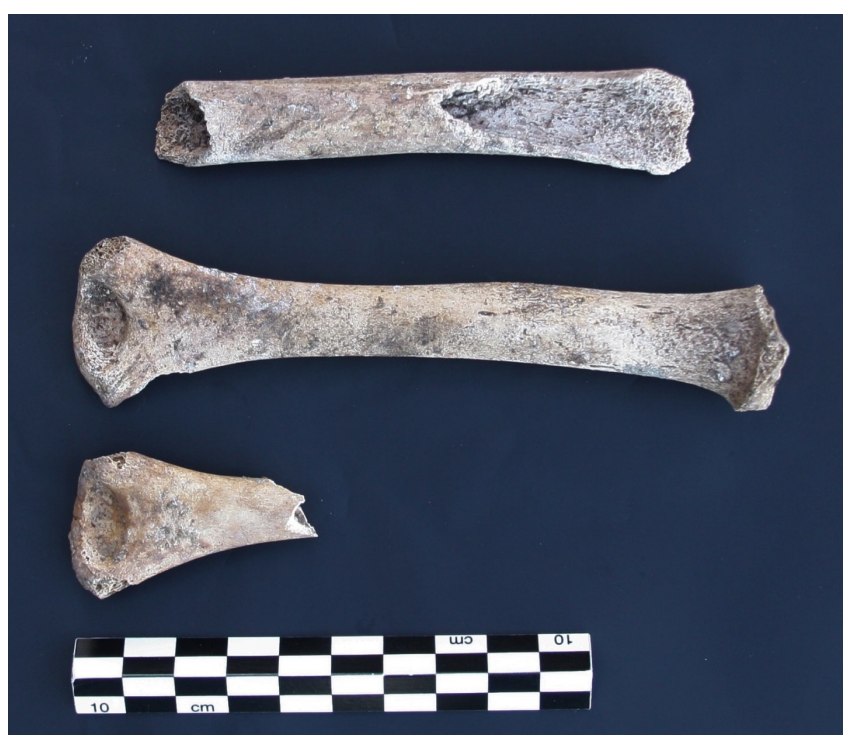

Figure 7. Three of the four subadult individuals in Operation VIII Lot 13 top to bottom: left humerus diaphysis (VIII-13-421), left humerus (VIII-13-260), and left humerus distal portion (VIII-13-117). 
rate markedly falls. As the youth learn what they can and cannot do in their environment the mortality rate continues to lessen. The curve reaches a low point between the ages of 5 and 10 years. The mortality rate gradually increases above the age of 10 years as individuals become young adults and assume the riskier roles of adulthood. Rebecca Storey (1985) compared the mortality curves of pre-Columbian Teotihuacan to Old World cities including Rome and London. She found Teotihuacan's mortality rates to be similar. These examples have their highest rates of mortality in the first year of life. All exhibit a marked drop of mortality between 1 and 5 years and a further drop in mortality between 5 and 10 years, before rising slightly between $10-14$ years.

The Midnight Terror Cave mortality curve is decidedly different from those of the populations discussed by Storey. Only $12.3 \%$ of the subadults are in the $0-1$ year old age category when mortality should be highest. Mortality rises sharply between 1 - 4 years of age (27.7\%) when it should be dropping and is highest between 5 - 10 years of age (42.2\%) when it should be lowest. Finally, $17.7 \%$ are between $11-16$ years old [Figure 8]. The modal age range represented in the juvenile remains at MTC is $5-10$ years old. The disparity between the normal mortality curve and that found in MTC persuasively argues that the individuals did not die of natural causes. Nor was the cause of deaths due to catastrophic events such as earthquakes, famine, or plague, where all age categories would be represented evenly in the collection (Paine \& Boldsen, 2002).

\section{Discussion}

This analysis of subadult remains is significant in several respects. First, it has documented a demographic pattern that is strikingly different than a normal mortality curve. The greatest number of individuals died at ages when mortality is generally low. Furthermore, the age pattern agrees well with Tozzer's (1941; and see note 535) observation that sacrificial victims were "often five or six years

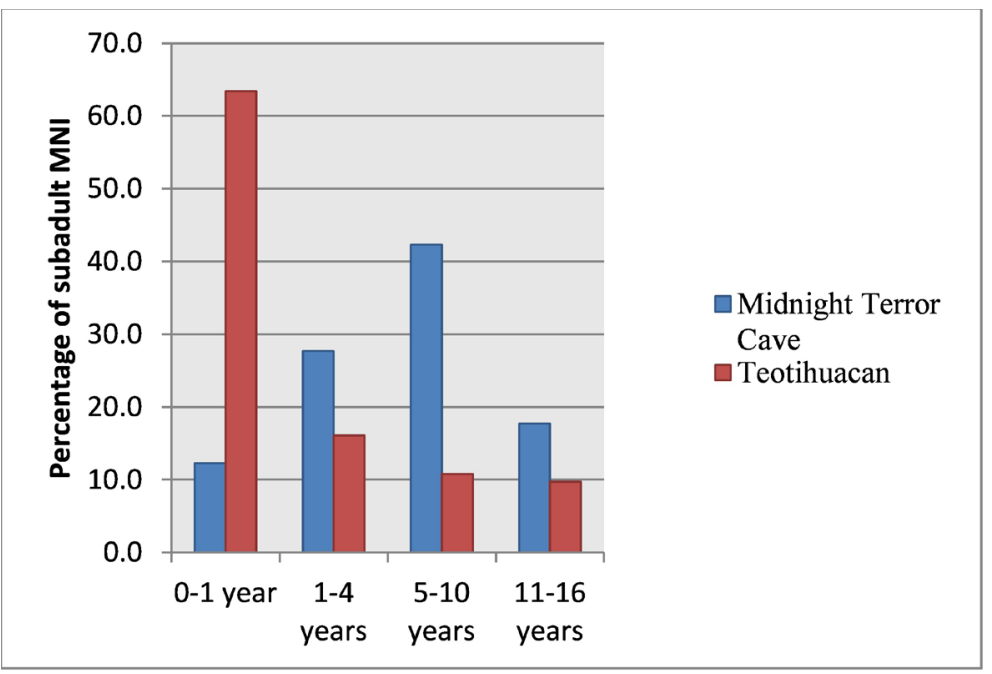

Figure 8. Graph contrasting a normal mortality curve (per Storey 1985) with the Midnight Terror Cave mortality curve. 
of age." Secondly, the Midnight Terror Cave osteological assemblage, the largest cave assemblage in the southern Maya lowlands, is sufficiently large that the pattern observed cannot be dismissed as a sampling error.

Based on their review of thirty-five Maya caves, cenotes, crevices and rock shelters Andrea Cucina and Vera Tiesler (2014) suggest that caves in general show a very different pattern than that documented for MTC. They note:

On the contrary, infants dying within the first 2 years of life (Infant 1 category) prevail in the caves, followed by a lower representation of infants from 3 up to about 10 years of age. This profile is somehow a "normal" distribution of mortality in preantibiotic populations, in which individuals during the first 2 years of life experience the highest rate of mortality (p. 243).

It appears, however, that this statement is not accurate. While we have not been able to examine all of the 20 caves they surveyed, we have checked the Petexbatun caves, NajTunich, Barton Creek Cave and the Cueva de Lazo, which between them contain three quarters of the "infants" they identified. In point of fact, there are many more children between the ages of three and ten than infants of less than two years of age. At Barton Creek Cave, for instance, nine children fell between 3 - 12 years of age while only three were younger than this, with another two adolescents between 12 and 18 (Owen, 2005). Caves do not mirror a normal mortality pattern but rather replicate the distribution noted at MTC.

Later, when they discuss all subterranean contexts, they recognize that these contexts have adult/subadult ratios differing from normal mortality rates:

Even though infant and subadult mortality was very high in prehistoric populations, we feel that the general frequency of infants and juveniles found in caves, cenotes, and other natural underground places compared to adults is clearly distinct from the natural mortality profile, denoting in some cases a cultural pattern involved in the preferential deposition of individuals in this age range (Cucina \& Tiesler, 2014, p. 243).

Cucina and Tiesler's pairing of caves and cenotes is particularly appropriate because, from the perspective of cave archaeology, both fall under the Maya term ch'een, generally translated as "cave" (Brady, 1997; Laughlin, 1975). This is even true in Yucatan where the site name Chichen Itza is generally accepted as referring to the Cenote of Sacrifice. The demographic pattern here is acknowledged as being very non-normal. Cucina and Tiesler (2014) state:

Conversely, the infant remains recovered from Chichen Itza's Sacred Cenote denote a preferential disposal of young individuals in the $6-12$ year range, with a frequency approximating $40 \%$ of all the individuals, with few younger than age five (corresponding to less than $10 \%$ of the whole sample). Such a distribution confirms a biased disposal choice or, much more likely, the selection of certain age groups for ritual discard in this sacred sinkhole (p. 243).

Lest the point be missed, the pattern of "ritual discard" that is generally accepted as reflective of sacrifice at the Sacred Cenote is precisely the same as the one documented at Midnight Terror Cave. Since the two features are concep- 
tually equivalent in Maya thought, the implications for MTC appear inescapable. The preliminary interpretation of sacrifice made during the recovery phase was, of necessity, based on contextual observations. Here, the osteological analysis made in the laboratory has further buttressed that interpretation.

This is not the only similarity between these two features. Hooten (1940) analyzed the cranial elements from Thompson's Cenote collection and identified 21 adults and 21 children under the age of 18 . Thus, half the victims were children. More recently, Lane Beck and April Sievert (2005) have reanalyzed the Peabody collection using all of the bones and have recognized 101 individuals, of which 51 are children. Frank Saul's (1975) notes on the Mexican cenote collection reported 29 adults and 29 children. Guillermo de Anda's (2007) much more thorough analysis of the Mexican collection found that of the 121 individuals identified on the basis of crania, 78 or $64 \%$ were children less than 18 years of age. Ultimately, 127 individuals were defined based on left tibias and 88 (69\%) of these belong to children. Clearly, the ratio of subadults and adults present in sacrificial contexts is more equal than originally believed. With the augmented subadult MNI provided by this study, it is clear that the composition of the Midnight Terror Cave assemblage is similar.

Attempting to develop a picture of the composition of the Maya sacrificial population from a myriad of sites containing a few examples is bound to produce confused and contradictory results because of the statistically small sample sizes. The fact that the only two large Maya sacrificial assemblages agree that about half of the population was composed of children provides a much clearer picture. This picture has important implications. First, adults composed only about half of the victims. While males predominate, females appear in substantial percentages (Cucina \& Tiesler, 2014) but neither adult group comes close to matching the size of the subadult population.

Turning to the subadult half of the population, the Yucatecan ethnohistoricsources record how children might have been acquired. Tozzer (1941) notes:

These children were obtained in several ways. Some were kidnapped, others were purchased. There seem to have been certain persons whose office (oficio) was to obtain children for sacrifice by kidnapping. We read of a boy" whom they brought from the Cupuls who was about four years old" and "two bought from the Cupuls." In another purchase, the price is given as "five red cuentas for each boy."... In two places a fathom of thick beads was paid for each of two boys who were to be sacrificed. Often the victims were orphans contributed by rich men who had taken them into their houses to bring up. These last were in some cases the offspring of deceased male relatives and slave women. ... (S) uch was the custom in ancient times that some caciques sent boys and girls to other caciques for sacrifice... (p. 117; and see note 535).

These mechanisms-kidnapping, purchase, and gift exchange-could all operate on a local level without engendering inter-polity strife so long as kidnapping did not target neighbors too frequently. While Traci Ardren (2011) is cor- 
rect in calling attention to the lack of discussion regarding child sacrifice, her argument that victims were in some way empowered by sacrifice is fanciful at best. We would argue instead that this system worked precisely because children in general are disempowered and unable to resist.

\section{Conclusions}

This article has presented the results of the analysis of subadult remains recovered from Midnight Terror Cave. We have made several significant points concerning this collection. First, the careful observation of age-at-death provides a morality curve that differs strikingly from what would be expected of a normal population. We have also argued that the caves surveyed by Cucina and Tiesler (2014) had comparable curves indicating the possibility of similar patterns of behavior. Secondly, we point out that the MTC curve is similar to that for the subadult remains from the Cenote of Sacrifice at Chichen Itza. We have shown that both caves and cenotes fall under the Maya term ch'een and so are conceptually equivalent. The Sacred Cenote's role in human sacrifice is well accepted so it should not be surprising if the same behaviors were occurring in caves. Third, MTC and the Sacred Cenote, the two largest Maya osteological assemblages attributed to sacrifice, suggest that half of all sacrificial victims may have been children. Greater attention must be paid to this segment of society if we are to gain a better-grounded understanding of Maya sacrifice.

Finally, Tiesler (2007) says, "Methodologically, the strong reliance on documentary and contextual data, coupled with the neglect of direct biographic and taphonomical evidence, has resulted (sic) equally detrimental for a full appreciation of mortuary pathways and a skewed or erroneous view of conduct they may represent (p. 16)." Conversely, lack of familiarity with ethnohistoric sources and an inability to use archaeological context by analysts attempting to limit the discussion to the osteological artifacts has been no less damaging. Rather than pointing fingers across a chasm, we have attempted to bridge the gap and hope that our efforts have produced a more encompassing analysis.

\section{Acknowledgements}

The archaeological exploration of Midnight Terror Cave was undertaken with the permission of the Belizean Institute of Archaeology. The authors would like to thank the former director, Dr. Jaime Awe, and the current director, Dr. John Morris, for their support. Heartfelt thanks from all members of the project are due the late Lloyd Cotsen whose generous grants made the project possible. The authors also wish to thank Matt Oliphant and Nancy Pistole for permission to reproduce their map. The authors wish to thank Cristina Verdugo, Melanie Saldaña, and Samantha Lorenz for reading earlier drafts of this paper. The authors also thank Dr. Elizabeth Miller who supported the research by providing access

to the California State University, Los Angeles forensic anthropology laboratory and skeletal materials throughout the project's duration. 


\section{References}

Anderson, M., Messner, M. B., \& Green, W. T. (1964). Distribution of Lengths of the Normal Femur and Tibia in Children from One to Eighteen Years of Age. Journal of Bone and Joint Surgery, 46, 1197-1202.

https://doi.org/10.2106/00004623-196446060-00004

Ardren, T. (2011). Empowered Children in Classic Maya Sacrificial Rites. Childhood in the Past, 4, 133-145. https://doi.org/10.1179/cip.2011.4.1.133

Bebbington, M., Lai, C. D., \& Zitikis, R. (2007). Modeling Human Mortality using Mixtures of Bathtub Shaped Failure Distributions. Journal of Theoretical Biology, 245, 528-538. https://doi.org/10.1016/j.jtbi.2006.11.011

Beck, L. A., \& Sievert, A. K. (2005). Mortuary Pathways Leading to the Cenote at Chichén Itzá. In G. F. M. Rakita, J. E. Buikstra, L. A. Beck, \& S. R. Williams (Eds.), Interacting with the Dead: Perspectives on Mortuary Archaeology for the New Millennium (pp. 290-304). Gainesville, FL: University Press of Florida.

Berryman, C. A. (2007). Captive Sacrifice and Trophy Taking among the Ancient Maya. In R. J. Chacon, \& D. H. Dye (Eds.), The Taking and Displaying of Human Body Parts as Trophies by Amerindians (pp. 377-399). New York, NY: Springer Press. https://doi.org/10.1007/978-0-387-48303-0_15

Black, S., \& Scheuer, L. (1996). Age Changes in the Clavicle: From the Early Neonatal Period to Skeletal Maturity. International Journal of Osteoarchaeology, 6, 425-434. https://doi.org/10.1002/(SICI)1099-1212(199612)6:5<425::AID-OA287>3.0.CO;2-U

Bonor, J. L. (1995). Excavación de Salvamento en Caves Branch Rock Shelter, Cayo District, Belize. IV Encuento Internacional Investigadores de la Cultura Maya, 1, 46-70.

Bonor, J. L., \& Klemm, C. M. (1995). Trabajos Recientes en la Región de Caves Branch, Distrito de el Cayo, Belice. Investigadores de la Cultura Maya, 4, 250-267.

Brady, J. E. (1989). An Investigation of Maya Ritual Cave Use with Special Reference to Naj Tunich, Peten, Guatemala. PhD Dissertation, Los Angeles, CA: University of California.

Brady, J. E. (1997). Settlement Configuration and Cosmology the Role of Caves at Dos Pilas. American Anthropologist, 99, 602-618. https://doi.org/10.1525/aa.1997.99.3.602

Brady, J. E. (2004). Constructed Landscapes: Exploring the Meaning and Significance of Recent Discoveries of Artificial Caves. Ketzalcalli, 1, 2-17.

Brady, J. E. (2012). The Architectural Cave as an Early Form of Artificial Cave in the Maya Lowlands. In J. E. Brady (Ed.), Heart of Earth: Studies in Maya Ritual Cave Use (pp. 61-68). Austin, TX: Association for Mexican Cave Studies.

Buikstra, J. E. (2007). The Bioarchaeology of Maya Sacrifice. In V. Tiesler, \& A. Cucina (Eds.), New Perspectives on Human Sacrifice and Ritual Body Treatments in Ancient Maya Society (pp. 293-307). New York, NY: Springer Press. https://doi.org/10.1007/978-0-387-48871-4_13

Buikstra, J. E., \& Ubelaker, D. H. (1994). Standards for Data Collection from Human Skeletal Remains: Proceedings of a Seminar at the Field Museum of Natural History. No. 44, Fayetteville, AR: Arkansas Archaeological Survey.

Coe, W. R. (1959). Piedras Negras Archaeology: Artifacts, Caches, and Burials. University Museum, University of Pennsylvania.

Cucina, A., \& Tiesler, V. (2014). Mortuary Pathways and Ritual Meanings Related to Maya Human Bone Deposits in Subterranean Contexts. In G. D. Wrobel (Ed.), The Bioarchaeology of Space and Place (pp. 225-254). New York, NY: Springer Press. 
https://doi.org/10.1007/978-1-4939-0479-2_9

Danforth, M. E., Wrobel, G. D., Armstrong, C. W., \& Swanson, D. (2009). Juvenile Age Estimation using Diaphyseal Long Bone Lengths among Ancient Maya Populations. Latin American Antiquity, 20, 3-13. https://doi.org/10.1017/S1045663500002480

De Anda Alanis, G. (2007). Sacrifice and Ritual Body Mutilation in Postclassical Maya Society: Taphonomy of the Human Remains from Chichen Itza's Cenote Sagrado. In V. Tiesler, \& A. Cucina (Eds.), New Perspectives on Human Sacrifice and Ritual Body Treatments in Ancient Maya Society (pp. 190-208). New York, NY: Springer Press. https://doi.org/10.1007/978-0-387-48871-4_8

Demarest, A. A., O’Mansky, M., Wolley, C., Van Tuerenhout, D., Inomata, T., Palka, J., \& Escobedo, H. (1997). Classic Maya Defensive Systems and Warfare in the Petexbatun Region: Archaeological Evidence and Interpretations. Ancient Mesoamerica, 8, 229-253. https://doi.org/10.1017/S095653610000170X

Fazekas, I. G., \& Kósa, F. (1978). Forensic Fetal Osteology. Budapest: AkadémiaiKiadó.

Fitzsimmons, J. L., \& Shimada, I. (2011). Living with the Dead: Mortuary Ritual in Mesoamerica. Tucson: University of Arizona Press.

Fowler, W. R. (1984). Late Preclassic Mortuary Patterns and Evidence for Human Sacrifice at Chalchuapa, El Salvador. American Antiquity, 49, 603-618. https://doi.org/10.2307/280364

Goodacre, C. J. (2012). Atlas of the Human Dentition. Shelton, CT: People's Medical Publishing House-USA.

Hooten, E. A. (1940). Skeletons from the Cenote of Sacrifice at Chichen Itzá. In C. L. Hay (Ed.), The Maya and Their Neighbors (pp. 272-280). New York, NY: D. Appleton-Century.

Ishihara-Brito, R., \& Guerra, J. (2012). Windows of the Earth: An Ethnoarchaeological Study on Cave Use in Suchitepéquez and Sololá, Guatemala. In J. E. Brady (Ed.), Heart of Earth: Studies in Maya Ritual Cave Use (pp. 51-60). Austin, TX: Association for Mexican Cave Studies.

Jeanty, P. (1983). Fetal Limb Biometry. Radiology, 147, 601-602. https://doi.org/10.1148/radiology.147.2.6836145

Kieffer, C. L. (2017). Sacrifice of the Social Outcasts: Two Cases of Klippel-Feil Syndrome at Midnight Terror Cave, Belize. International Journal of Osteoarchaeology, 27, 45-55. https://doi.org/10.1002/oa.2456

Kimura, K. (1992). Estimation of Stature from Second Metacarpal Length in Japanese Children. Annals of Human Biology, 19, 267-275. https://doi.org/10.1080/03014469200002132

Klepinger, L. L. (2006). Fundamentals of Forensic Anthropology. Hoboken, NJ: John Wiley \& Sons. https://doi.org/10.1002/0470007729

Lai, C. D. (2012). Human Mortality Curves that Decelerate to a Plateau. Mathematical and Computer Modelling, 55, 1118-1128. https://doi.org/10.1016/j.mcm.2011.09.036

Laughlin, R. M. (1975). The Great Tzotzil Dictionary of San Lorenzo Zinacantan (No. 19). Washington DC: Smithsonian Contributions to Anthropology. https://doi.org/10.5479/si.00810223.19.1

Lee, T. A., \& Clark, J. E. (1988). Oro, Tela y Xute: Investigaciones Arqueológicas en la Región Cancum, Colonia Las Delicias, Chiapas. Arqueología, 4, 7-46.

Lee, T. A., Hayden, B., \& Walker, P. L. (1988). San Pablo Cave and El Cayo on the Usumacinta River, Chiapas, Mexico (No. 53). Papers of the New World Archaeological Foundation. Provo, UT: Brigham Young University. 
Lewis, M. E. (2007). The Bioarchaeology of Children: Perspectives from Biological and Forensic Anthropology (Vol. 50). New York, NY: Cambridge University Press.

López Austin, A. (1980). Cuerpo Humano e Ideologia. Las Concepciones de los Antiguos Nahuas.

Malvido, E., Pereira, G., \& Tiesler, V. (1997). El Cuerpo Humano y su Tratamiento Mortuorio (Vol. 344). Mexico City: Instituto Nacional de Antropología e Historia. https://doi.org/10.4000/books.cemca.2493

Manzanilla, L., \& Sánchez, C. S. (2003). Prácticas Funerarias en la Ciudad de los Dioses: Los Enterramientos Humanos de la Antiqua Teotihuacan. Primera Reimpresión. Mexico City: Instituto de Investigaciones Antropológocas, Universidad Nacional Autónoma de México.

Manzanilla, L., López, C., \& Freter, A. (1996). Dating Results from Excavations in Quarry Tunnels behind the Pyramid of the Sun at Teotihuacan. Ancient Mesoamerica, 7, 245-266. https://doi.org/10.1017/S0956536100001450

Maresh, M. M. (1970). Measurements from Roentgenograms. In R. W. McCammon (Ed.), Human Growth and Development (pp. 157-200). Springfield, IL: C.C. Thomas.

Morris, W. F. (1986). Maya Time Warps. Archaeology, 39, 52-59.

Odita, J. C., Okolo, A. A., \& Ukoli, F. (1991). Normal Values for Metacarpal and Phalangeal Lengths in Nigerian Children. Skeletal Radiology, 20, 441-445. https://doi.org/10.1007/BF00191088

Osterholtz, A. J., Baustian, K. M., Martin, D. L., \& Potts, D. T. (2014). Commingled Human Skeletal Assemblages: Integrative Techniques in Determination of the MNI/MNE. In A. J. Osterholtz, K. M. Baustian, \& D. L. Martin (Eds.), Commingled and Disarticulated Human Remains (pp. 35-50). New York, NY: Springer Press.

Owen, V. A. (2005). A Question of Sacrifice: Classic Maya Cave Mortuary Practices at Barton Creek Cave, Belize. In K. M. Prufer, \& J. E. Brady (Eds.), Stone Houses and Earth Lords: Maya Religion in the Cave Context (pp. 323-340). Boulder, CO: University Press of Colorado.

Paine, R. R., \&Boldsen, J. (2002). Linking Age-at-Death Distributions and Ancient Population Dynamics: A Case Study. In R. D. Hoppa, \& J. W. Vaupel (Eds.), Paleodemography: Age Distribution from Skeletal Samples (pp. 169-180). New York, NY: Cambridge University Press.

Pendergast, D. (1971). Excavations at Eduardo Quiroz Cave, British Honduras (Belize), Royal Ontario Museum Art and Archaeology Occasional Papers No. 21. Toronto: Royal Ontario Museum.

Prufer, K. M. (1997). Pilgrimages for the Dead: Early Classic Mortuary Cavesin Southwestern Belize. Paper Presented at the 62nd Annual Meeting of the Societyfor American Archaeology, Nashville.

Reents-Budet, D., \& MacLeod, B. (1986). The Archaeology of Petroglyph Cave, Belize. Unpublished Manuscript.

Ricketson, O. (1925). Burials in the Maya Area. American Anthropologist, 27, 381-401. https://doi.org/10.1525/aa.1925.27.3.02a00030

Saul, F. P. (1975). The Maya \& Their Neighbors (1974): As Recorded in Their Skeletons. In The Maya and Their Neighbors (pp. 35-40). Cambridge, MA: The Peabody Museum, Harvard University.

Saul, J. M., Prufer, K. M., \& Saul, F. P. (2005). Nearer to the Gods: Rockshelter Burials from the EkXux Valley, Belize. In K. M. Prufer, \& J. E. Brady (Eds.), Stone Houses and Earth Lords: Maya Religion in the Cave Context (pp. 297-323). Boulder, CO: Universi- 
ty Press of Colorado.

Saunders, S., Hoppa, R., \& Southern, R. (1993). Diaphyseal Growth in a Nineteenth-Century Skeletal Sample of Subadults from St. Thomas' Church, Belleville, Ontario. International Journal of Osteoarchaeology, 3, 265-281. https://doi.org/10.1002/oa.1390030405

Scheuer, L., \& Black, S. (2000). Developmental Juvenile Osteology. San Diego, CA: Elsevier Academic Press.

Scheuer, L., \& Black, S. M. (2009). Developmental Juvenile Osteology: A Laboratory and Field Manual. San Diego, CA: Elsevier Academic Press.

Scheuer, L., \&MacLaughlin-Black, S. (1994). Age Estimation from the Pars Basilaris of the Fetal and Juvenile Occipital Bone. International Journal of Osteoarchaeology, 4, 377-380. https://doi.org/10.1002/oa.1390040412

Schrenk, A. (2017). Subadult Age at Death and Health Status at Niah Cave, Borneo (1500-200 BC). International Journal of Osteoarchaeology, 27, 801-812. https://doi.org/10.1002/oa.2594

Scott, A. M. (2009). Communicating with the Sacred Earthscape: An Ethnoarchaeological Investigation of Kaqchikel Maya Ceremonies in Highland Guatemala. PhD Dissertation, Austin, TX: The University of Texas.

Sepúlveda, H. (1977). Ceremonias de Petición de Lluvias. Revista Mexicana de Estudios Antropológicos, 23, 345-363.

Spence, M. W., White, C. D., Longstaffe, F. J., \& Law, K. R. (2004). Victims of the Victims: Human Trophies Worn by Sacrificed Soldiers from the Feathered Serpent Pyramid, Teotihuacan. Ancient Mesoamerica, 15, 1-15.

https://doi.org/10.1017/S0956536104151018

Steele, D. G., \& Bramblett, C. A. (1988). The Anatomy and Biology of the Human Skeleton. College Station, TX: Texas A\&M University Press.

Storey, R. (1985). An Estimate of Mortality in a Pre-Columbian Urban Population. American Anthropologist, 87, 519-535. https://doi.org/10.1525/aa.1985.87.3.02a00010

Thompson, J. E. S. (1975). Introduction to the Reprint Edition. In H. C. Mercer (Ed.), The Hill-Caves of Yucatan (pp. 7-44). Norman: University of Oklahoma Press.

Tiesler, V. (2005). What Can the Bones Really Tell Us? The Study of Human Skeletal Remains from Cenotes. In K. M. Prufer, \& J. E. Brady (Eds.), Stone Houses and Earth Lords: Maya Religion in the Cave Context (pp. 341-364). Boulder, CO: University Press of Colorado.

Tiesler, V. (2007). Funerary or Nonfunerary? New References in Identifying Ancient Maya Sacrificial and Postsacrificial Behaviors from Human Assemblages. In V. Tiesler, \& A. Cucina (Eds.), New Perspectives on Human Sacrifice and Ritual Body Treatments in Ancient Maya Society (pp. 14-44). New York, NY: Springer Press. https://doi.org/10.1007/978-0-387-48871-4_2

Tocheri, M. W., \& Molto, J. E. (2002). Aging Fetal and Juvenile Skeletons from Roman Period Egypt using Basiocciput Osteometrics. International Journal of Osteoarchaeology, 12, 356-363. https://doi.org/10.1002/oa.634

Tozzer, A. M. (1941). Landa's Relacion de las Cosas de Yucatan: A Translation. Cambridge, MA: Peabody Museum of American Archaeology and Ethnology, Harvard University.

Trotter, M., \& Peterson, R. R. (1969). Weight of Bones during the Fetal Period. Growth, 33, 167-184.

Ubelaker, D. H. (1978). Human Skeletal Remains: Excavation, Analysis, Interpretation. 
Chicago, IL: Aldine Publishing.

Ubelaker, D. H., \& Rife, J. L. (2008). Approaches to Commingling Issues in Archeological Samples: A Case Study from Roman Era Tombs in Greece. In B. J. Adams, \& J. E. Byrd (Eds.), Recovery, Analysis, and Identification of Commingled Human Remains (pp. 97-122). Totowa, NJ: Humana Press. https://doi.org/10.1007/978-1-59745-316-5_6

Vogt, E. Z. (1969). Zinacantan: A Maya Community in the Highlands of Chiapas. Cambridge, MA: Harvard University Press. https://doi.org/10.4159/harvard.9780674436886

Vogt, E. Z., \& Stuart, D. (2005). Some Notes on Ritual Caves among the Ancient and Modern Maya. In J. E. Brady, \& K. M. Prufer (Eds.), In the Maw of the Earth Monster: Mesoamerican Ritual Cave Use (pp. 155-185). Austin, TX: University of Texas Press.

Weiss, K. M., \& Wobst, H. M. (1973). Demographic Models for Anthropology. Memoirs of the Society for American Archaeology, No. 27, i-186.

White, T. D., Black, M. T., \& Folkens, P. A. (2011). Human Osteology. London: Academic Press.

Willard, T. A. (1926). The City of the Sacred Well. New York, NY: The Century Co.

Wrobel, G., Tyler, J., \& Hardy, J. (2007). Rockshelter Excavations in the Caves Branch River Valley. Research Reports in Belizean Archaeology, 4, 187-196.

Wylie, A. (1985). The Reaction against Analogy. Advances in Archaeological Method and Theory, 8, 63-111. https://doi.org/10.1016/B978-0-12-003108-5.50008-7 